\title{
The Effect of Psychological Empowerment on Innovative Work Behavior: The Mediating Role of Employee Voice
}

\author{
Edward Kofi Krupah \\ College of Economics and Management, Nanjing University of Aeronautics and Astronautics, \\ Nanjing-21106, China
}

\begin{abstract}
The importance of innovative work behavior cannot be downplayed as it functions as a key variable through which novel ideas translates into innovative outputs enabling businesses to survive and thrive. The study investigated the effect of psychological empowerment on employee innovative work behavior by examining the mediating role of employee voice in Ghana. This was done to address the lack of research on this topic, as well as to contribute to the long-term strategic vision of the government of Ghana and foster innovation in the nation. Data from 200 full-time Ghanaian workers was used in this cross-sectional study. Employing Pearson's correlation, linear regression and SEM, the empirical findings from the study demonstrates that psychological empowerment and employee voice correlates significantly and positively with innovative work behavior. Employee voice (promotive and prohibitive) sustained a favorable impact on innovative work behavior and also mediated the effect of psychological empowerment on employee innovative work behavior. The inference of this research implies that the government of Ghana and employers strengthen programs that integrate practices to increase employee psychological empowerment levels as a way of stimulating higher levels of innovative capabilities and also encourage employee voice primarily for the purpose of communicating ideas for organizational development.
\end{abstract}

Keywords: Psychological Empowerment, Voice, Innovative Work Behavior, Ghana

DOI: $10.7176 / \mathrm{EJBM} / 13-18-10$

Publication date:September $30^{\text {th }} 2021$

\section{Introduction}

In a dynamic and constantly evolving corporate environment we find ourselves in today resulting from technological advancement, the notion of innovative work behavior cannot be downplayed as it functions as the womb through which conceptualized novel ideas manifest into innovative outputs (Jong \& Hartog, 2008). This enables businesses to survive, relinquish the status quo, thrive, and sustain a competitive edge in a highly competitive market system. For this reason, organizations are compelled to constantly be on their feet in order to provide ground-breaking products and services for the very purpose of achieving sustainable development, growth, and meeting market demands. On the contrary, failure to meet market demands could trigger market share losses and business demotion or relegation as in the case of many organizations whose competency failed to positively correlate with today's fierce competitive market structure (Martins, 2021). Innovative work behavior enables organizations to augment the production of quality organizational output required for advancing businesses and positively improve decision-making for better management of resources.

Previous research have investigated individual and organizational elements influencing innovative work behavior. Some of the antecedents that were explored in the study included leadership behavior, emotional intelligence, intellectual capital, knowledge sharing, work centrality, self-determined motivation, personorganizational fit, pay justice, and quality culture (Akram et al., 2016; Asurakkody \& Kim, 2020; Dincer et al., 2011; Ghani et al., 2009a; Örnek \& Ayas, 2015; Saether, 2019; Volery \& Tarabashkina, 2021). The influence of promotive and prohibitive voice on innovative work behavior has only been studied by Miao et al., (2020). There is also a lack of empirical research that have investigated the significance of psychological empowerment in enhancing innovative work behavior (Abdullatif et al., 2016; Çekmecelioğlu \& Özbağ 2014). Furthermore, these studies focused on Western and Asian cases, depriving the research community of other different demographic perspectives.

As it remains the primary objective of leaders to succeed in their undertakings and to see their vision flourish in the production of innovative outputs, it is imperative to understand that having a psychologically empowered workforce who are passionately involved in their work becomes a vital component to the fulfillment of organizational goals. It is asserted that psychological empowerment affects employee creative intention which is a vital step for innovation to take place (Sun et al., 2012). Psychological empowerment can be equated to intrinsic motivation that affects and stimulates the mind towards the desired course to produce the desired result (Dewettinck \& Van Ameijde, 2011; Seibert et al., 2011)

Furthermore, in order to understand some of the key factors affecting innovative work behavior, the facilitation of voice as a mediating construct is to certify with empirical evidence the significance of communication, established as one of the primary engagements needed towards building a successful 
organization and a way of fostering creative and innovative ideas (Chen \& Hou, 2016; Yan \& Xiao, 2016). Employee voice serves as an imperative factor for leaders to give considerable attention to, because leaders play a critical role in the voice process by examining the communication of ideas that can result in innovation. (Detert \& Burris, 2007)

Innovation is an important phenomenon in organizations in Ghana because of the need for sustainable development (Connors \& Press-Williams, 2016; NEIP, 2020). Ghana is recognized as a forceful emerging economy (Edmond, 2019) with a lot of innovative potentials, taking into account the abundance of natural resources at her disposal, accredited as Africa's second-largest producer of gold and the world's second-largest producer of cocoa (Ikenwa, 2020; Quartey-Papafio et al., 2021). Nonetheless, potential that is underutilized or unrealized cannot benefit any organization or propel the economy forward. For this reason, the National Entrepreneurship and Innovation Programme (NEIP) was launched as part of Ghana's long-term strategic vision, with the goal of providing business development services, startup incubators, and funding for emerging enterprises to help them grow and succeed (NEIP, 2020). This vision is also determined to relieve or attenuate Ghana's current prevailing problem of unemployment. The government of Ghana and organizational leaders believe that creativity and innovation are key to propelling and enhancing organizational activities in Ghana. Hence encouraging the notion of innovative work behavior is acclaimed towards actualizing Ghana's national vision as it sustains the capacity to increase the productivity of the nation (Artwatch, 2017; NEIP, 2020).

In addition, research (Oduro \& Nyarku, 2018) on innovation in Ghana disclosed that incremental innovation techniques boosted company performance in terms of higher customer satisfaction and loyalty, sales growth, competitiveness, and worldwide market reach. Thereby makes this study crucial to further help us investigate the contributing factors affecting innovative behavior. This study examines the combined influence of psychological empowerment and employee voice on innovative work behavior in Ghana, drawing from self-efficacy and innovation theory. The empirical finding of this study would contribute to the existing literature on innovative work behavior, as emerging from an economy where very little empirical research has been conducted, thus giving scholars a more holistic view on this vital subject. It would also contribute to the literature on empowerment and voice by providing empirical evidence on the relationship between psychological empowerment and employee voice.

\section{Theoretical Background}

\subsection{Innovative work behavior}

The idea of innovative work behavior differs from employee creativity. De Dreu et al., (2012) defined creativity as "the generation of insights, solutions, and ideas that are novel and potentially useful". However, Jong \& Hartog, (2008) defined innovative work behavior as 'an individual's behavior that aims to achieve the initiation and intentional introduction (within a work role, group or organization) of new and useful ideas, processes, products or procedures as well as the implementation of those ideas" thereby revealing the dimension of idea implementation for the fulfillment of a given task which eventually results in creative output. Mumford et al., (1997) noted that employee creativity is paramount and integral for organizational success, for this reason, central to the innovative process. It is key to note that as important as creativity is, ideas that are simply generated will not benefit an organization unless attention is given to it for its implementation. The implementation of innovative and creative ideas is the revelation and prime intention of innovative work behavior so that companies can actually realize new work procedures, processes and technological inventions that may be beneficial for organizational advancement in this technology driven age. Innovative work behavior can improve organizational marketing and financial performance, attract more clients and help organizations explore potential markets for market growth as well as enhancing firm competitiveness which is crucial for organizational survival (Martins, 2021). For this reason innovative behavior should be encouraged.

Moving from the conventional 2 or 3-dimensional scale in measuring innovative behavior as often used by researchers (Niesen et al., 2017; Scott \& Bruce, 1994), Jong \& Hartog, (2008) developed a four dimension scale that measured innovative work behavior. These dimensions include idea exploration which involves the discovery and identification of opportunities, problems, and complex puzzles arising in an organization that needs to be solved to improve working conditions or avert potential threats that may cause operational problems to organizational functionality (Amabile, 1988; Basadur, 2004; Jong \& Hartog, 2008; Parnes, S.J., 1977). Idea generation, which takes account of the construction of new ways to solve an issue; this is intended to improve and enhance working procedures, processes, products and services or gaining entry into new markets and expand organizational operations (Amabile, 1988; Jong \& Hartog, 2008; Kanter, 1988; Van de Ven, 1986). A third of the process is idea championing which factors in one's ability to successfully pitch and sell a novel idea, form coalitions and gain support from colleagues and senior management staff; this is needed in overcoming opposition granting an employee the advantage of persuading influential personnels in an organization (Howell \& Higgins, 1990; Jong \& Hartog, 2008; King \& Anderson, 2002; Van de Ven, 1986). Last of the innovative work behavior dimension is idea implementation. For ideas to be implemented this necessitates that one has a 
result-oriented attitude to transform an idea into a practical workable product, service, or new procedure that sustains the capacity to enhance organizational performance (Jong \& Hartog, 2008; Kanter, 1988; Van de Ven, 1986; West \& Farr, 1990).

\subsection{Psychological empowerment}

There is no doubt that psychological empowerment is essential in the workplace today, as it is utilized as a means to help firms get the most out of their employees (Durrah et al., 2014). Psychological empowerment is defined by Seibert et al., (2011) as "intrinsic task motivation reflecting a sense of self-control concerning one's work and an active involvement with one's work role". Drawing from Thomas \& Velthouse, (1990) model, Spreitzer, (1995) developed four-dimensional scale to measure psychological empowerment, and these include, meaning, competence, self-determination, and impact. Meng et al., (2015) writes in her work and describes meaningful work referring to 'the degree of employees' work goals in keeping with their beliefs or values". Competence was described as "a belief, and confidence employees have in their skills and within their scope of capability to perform their work well". Self-determination is explained as "the feelings of being in control of work and has the option over the initiation and continuation of work behaviors and processes". The last dimension is the impact which is defined as "the degree to which one can influence administrative operations at work".

\subsection{Voice behavior}

Maynes \& Podsakoff (2014) defined voice as “an individuals' voluntary and open communication directed toward individuals within the organization that is focused on influencing the context of the work environment". This study intends to explore two voice types, namely promotive voice and prohibitive voice. In line with Van Dyne, L., \& LePine, (1998) original conceptualization, Maynes \& Podsakoff (2014) define promotive voice as "employee expression of new ideas or suggestions for improving the overall functioning of their work unit or organization". He also defines prohibitive voice as "describing employees' expressions of concern about work practices, incidents, or employee behavior deemed harmful to their organization". Employee voice has been discovered to be crucial for organizational success and has been used to reveal the formation mechanism of organizational innovativeness (Miao et al., 2020). Voice has not only been demonstrated as a tangible exhibition of one's involvement in organizational decision-making, but also an essential form of employee contribution to the organization. Employee voice helps improve organizational innovativeness, team and organizational performance, and also contributes to the improvement of employee job engagement. The engagement of voice also reveals employee organizational citizenship behavior (Salman et al., 2020).

\subsection{Conceptual Model}

The conceptual model, illustrated in Figure 1 shows that innovative work behavior is a function of psychological empowerment and employee voice. This is because when an employees' job is meaningful to him/her and is given the opportunity to exercise autonomy in the execution of work assignments, this leads to the cultivation of innovative work behavior. The exploration and implementation of employee ideas makes employees become more confident in their abilities to meet managerial goals and motivates them to begin to champion and communicate even more innovative ones. This cognitive state of self-determination and the drive to make an impact positively translate into innovation which in turn leads to organizational advancement.

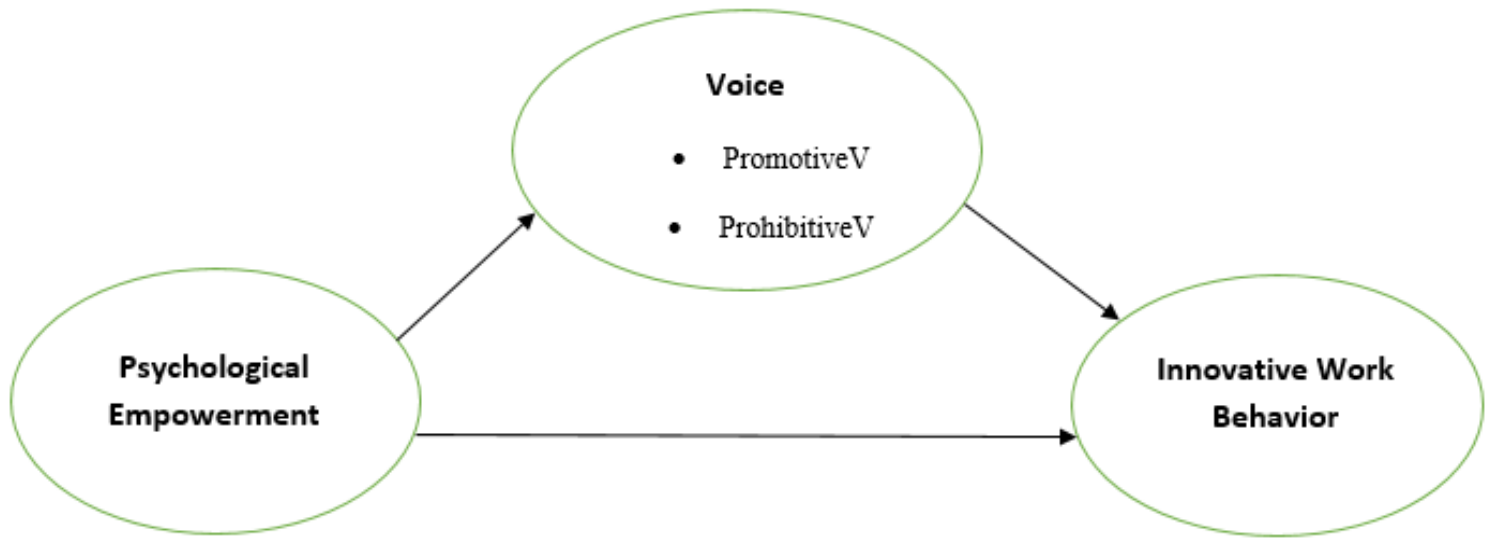

Figure 1. Conceptual Model 


\subsection{Hypothesis Development}

2.5.1 Psychological empowerment and Innovative work behavior

Ayoub et al., (2018) asserted that "psychological empowerment emphasizes individual subjective experience on being empowered". Much of the previous literature is expressive of the view that empowerment operationally powers employees' creativity positively (Amabile, 1983; Sun et al., 2012; Zhang \& Bartol, 2010). Amabile (1983) asserted that employees that are empowered will be most creative, thereby innovative when intrinsically motivated. Furthermore, her discovery on employee behavior revealed that the attentiveness given by employees in job tasks kept cumulating rather than instituted organizational reward and punishment system. This disposition acted as a stimulus to creativity, a precursor to innovative work behavior Jong \& Hartog (2008); Additionally, employees are found to produce fresh ideas when permitted to exercise autonomy and were at liberty to choose how to go about performing their work as they determined and set out task objectives.

Leaders who empower employees to find more meaning in their work without obstruction, allowing them to responsibly operate and have a sense of self-determination (autonomy) in prosecuting their assigned job duties, can boost employee innovative work behavior. Furthermore, Spreitzer (1995) noted that leaders who furnished employees with the necessary tools to aid employee competence, giving them the prospect to make an organizational impact, increased employee creativity.

Ghani et al., (2009b) in their study, discovered that psychological performance significantly related to innovative behavior as they investigated the private higher education institution in Malaysia. Bhatnagar, (2005) postulated that psychological empowerment positively correlated to employee work engagement. In turn, it colligated positively with innovation, therefore as employees get more involved in their work, finding absolute meaning in executing their job duties can augment their innovative prowess. On the premise of these discoveries, we postulate that psychological empowerment will have a positive impact on employee innovative work behavior.

Hypothesis 1: Psychological empowerment will positively influence employee creative performance

\subsubsection{Psychological empowerment and voice}

Wei et al., (2020) research findings on employee psychological empowerment and its impact on employee voice as moderated by organizational justice demonstrated that psychological empowerment was connected to and explained variance in voice. He also emphasized the significance of employees' psychological empowerment as a weapon wielded for organizations to fulfill their purpose effectively, noting its efficacy to undergird and help sponsor sound voice behavior. Bae et al., (2011) have discussed that if employees believe they have control over their work output, this should encourage voice behavior while also raising and refining the quality of voice types, by implication promotive and prohibitive voice. It is judicious and logical for a psychologically empowered employee whose job is meaningful to him/her and is self-assured of his/her capabilities to perform their work duties to communicate ideas that seek to promote organizational status quo by proactively voicing out constructive suggestions that may influence the organization and help the enterprise reach its goals. Consequently, an employee who has significant possibility for independence and freedom in how they conduct their job and whose work activities have an impact on organizational performance has the psychological obligation of reporting coordination difficulties in the workplace to management as a manifestation of prohibitive voice. Raub \& Robert (2013) asserted that empowered employees may be quicker to identify work complications or issues that occur outside their immediate sphere of work responsibility and more prone to take initiatory steps to help their co-workers or voice ideas for constructive developments. Thus on these grounds of the above investigations, this study posits that psychological empowerment will positively influence employee voice.

Hypothesis 2: Psychological empowerment will positively influence employee voice

Hypothesis 2a: Psychological empowerment will positively influence promotive voice

Hypothesis 2b: Psychological empowerment will positively influence prohibitive voice

\subsubsection{Voice behavior and Innovative work behavior}

Zhou \& George (2001) observed employee creativity as an expression of voice. Employee voice impacts the supervisor rating of their perception of employee innovative work behavior as voice serves as a conveyer of innovative ideas. Promotive voice is expected to foster creativity estimations because employee voice can deliver novel and intelligent ways of processing work activities. Conversely, prohibitive voice can also augment innovative work behavior as it seeks to address and avert potentially harmful practices or behaviors that could inhibit productivity hence paving the way for the introduction of new and effective ideas to find expression at the workplace for proper work functionality. Though voice expression particularly prohibitive voice type may possess some level of risk, as it is perceived as challenging organizational practices, however when an idea is communicated honestly and respectfully out of genuine concern for continual organizational progress, it is easier for employees to point out issues that may derail an organization from its course of operation to a reasonable 
supervisor. Avey et al., (2012) and Walumbwa et al., (2012) contributed to enhance the position of voice behavior and its influence on creativity by discovering that voice behavior was positively associated to employees' creativity.

Miao et al., (2020) also discovered that promotive as well as prohibitive voice positively and significantly relates to innovative work behavior. The study further revealed that both promotive and prohibitive voice behavior partially mediated the relationship between high-performance work systems and innovative work behavior. Therefore, on the strength of these empirical findings, this study predicts that employee voice will positively influence employee innovative work behavior.

Hypothesis 3: Employee voice will positively influence innovative work behavior

Hypothesis 3a: Promotive voice will positively influence innovative work behavior

Hypothesis 3b: Prohibitive voice will positively influence innovative work behavior

\subsubsection{The mediation of voice}

Psychological empowerment reveals the cognitive state of the employee which further translates into actions, directed towards achieving organizational goals and objectives based on intrinsic motivation and confidence in one's knowledge and skill to effectively execute a job task (Spreitzer, 1995). Spreitzer (1995) further postulates that psychological empowerment is a key determinant and predictor of innovative behavior. A psychologically empowered employee can impact his/her organization through the engagement of voice. Voice has been asserted to be an instrument connecting contextual factors and creativity (Chen \& Hou, 2016; Zhou \& George, 2001). Therefore, employee promotive voice sustains the capacity to deliver innovative concepts and ideas that have been explored and generated through high cognitive processes. On the other hand, employee prohibitive voice can also help identify problems in processes and procedures in the workplace that can impede organizational progress (Van Dyne et al., 2003; Liang et al., 2012). On the strength of these discoveries, this study hypothesizes that employee voice will mediate the relationship between psychological empowerment and innovative work behavior.

Hypothesis 4: Employee voice will mediate the relationship between Psychological Empowerment and innovative work behavior

Hypothesis 4a: Promotive voice will mediate the relationship between Psychological Empowerment and innovative work behavior

Hypothesis 4b: Prohibitive voice will mediate the relationship between psychological empowerment and innovative work behavior.

\section{Methodology}

\subsection{Data sample}

In this study, primary data collection was taken from both public and private sector organizations in Ghana which included start-ups, SME's, and large cooperation's. Two distinct questionnaires were designed and distributed to respondents in these organizations spreading through various functional divisions across different industries to aid the empirical study. A link to the questionnaire was generated as it was attached in an e-letter guaranteeing confidentially and anonymity. Potential participants were made to know that their decision to participate in the survey was completely voluntary and without monetary incentives. The e-letter was distributed via WhatsApp, E-mails and SMS.

The first questionnaire was completed by leaders in supervisory and managerial capacity who directly oversee segments of the organizational workforce. This was to facilitate the measuring of employee innovative work behavior and employee voice to prevent respondent bias on the part of employees. The second questionnaire was administered to their corresponding subordinate(s)/employee(s) to measure psychological empowerment.

Out of 320 questionnaires that was distributed, a total of 200 data was received from respondents. 135 of the respondents worked in the private sector whiles 65 comprised of the workforce in the public sector. 111 of the 200 respondents were represented by males and 89 by females. 33 of the respondents, worked in the healthcare/Pharmaceutical industry, 29 in the construction/manufacturing industry, 26 in the financial industry, 25 belonged to the media/entertainment/telecommunication industry whiles 17 worked in the computer industry. The rest were spread across service sectors in Ghana such as Education (13), Energy (12) Hospitalities (11), Transport (4), Agriculture (3), Civil service (13) and other Services (14). Among them that participated in the questionnaire 144 were graduates, 40 postgraduates and 16 possessed high school diplomas. 146 of these employees had working experience ranging from 0-5 years, 27 of them had an experience of 6-10 years and 27 possessed 11 years and above working experience. Finally, 116 of the employees were between 20-29 years of age, 61 were within the range of 30-39 years and 23 were 40 years and above old. 


\subsection{Measurement}

\subsubsection{Innovative work behavior}

The 4-dimension measurement scale developed by Jong \& Hartog (2008), was used to measure innovative work behavior. The dimensions includes idea exploration, idea generation, idea championing, and idea implementation. This scale of measure consists of 10 items. The first 2 items measured idea exploration; the second 3 items measured idea generation, the third 2 items measuring idea championing, and the last 3 items measuring idea implementation. A sample item included," How often does this employee pay attention to issues that are not part of his daily work?" The items were scored by a 5-point Likert scale rating (1- never, 2- rarely, 3- sometimes, 4often, 5-always). The Cronbach Alpha for this study is 0.9039.

\subsubsection{Psychological Empowerment}

The psychological empowerment scale advanced by Spreitzer (1995) was applied in measuring this construct. Four subscales developed with 12 items expressive of the scale: meaningful work ( 3 items), competence ( 3 items), autonomy ( 3 items), and impact ( 3 items). A sample item included "I am confident about my ability to execute my job". The items were scored by a 5-point Likert scale rating (1- strongly disagree, 2- disagree, 3neutral, 4- agree, 5-strongly agree). The Cronbach Alpha for this study is 0.895 .

\subsubsection{Voice - Promotive and prohibitive voice}

The ten items devised by Liang et al., (2012) were employed to measure employee voice. This was utilized in assessing supervisor ratings of their employees' promotive and prohibitive voice. A sample item included, "My employee, advise other coworkers against unpleasant behaviors that would impede job performance". The items were scored by a 5-point Likert scale rating (1- strongly disagree, 2- disagree, 3- neutral, 4- agree, 5-strongly agree). The Cronbach Alpha for this study is 0.854 .

\subsubsection{Data Analysis}

Following recommendations from Babin \& Anderson (2014), structural equation model (SEM) and linear regression were employed in performing data analysis. Using the STATA 16 statistical software tool, confirmatory factor analysis was employed to properly test the validity of the hypothesized model. Descriptive statistics which include mean and standard deviation were generated. Internal consistency and generalizability were checked using Cronbach alpha. The mediating analysis was carried out using STATA 16 following Baron and Kenny (1986) mediation testing approach.

\section{Results}

Structural equation model estimations of the study

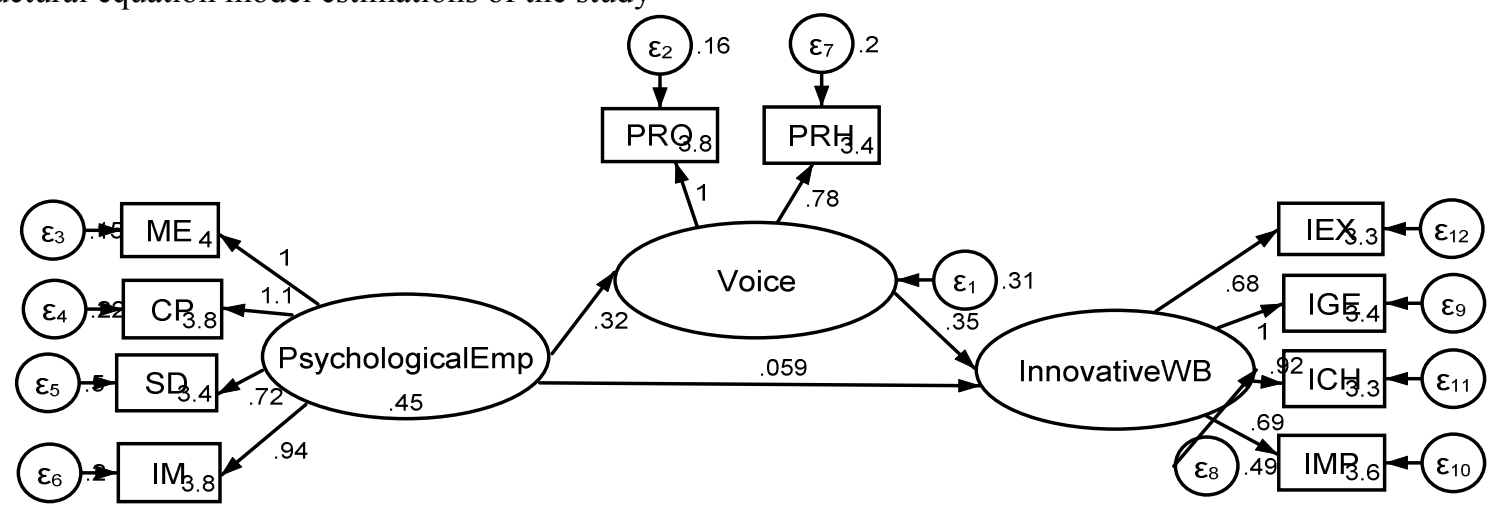

Figure 2 SEM model estimation

Table 1 shows the statistical fit for the model presented by figure 2 . The insignificance in the good square significance of fit, $\mathrm{p}=0.206$ is evident that the model is a close-fit. Subsequently, the incremental fit indices, TLI and CFI values also indicate a very good fit as the values are $>0.95$ SRMR value of $0.041(<0.05)$ indicates a close-fitting model. Lastly the RMSEA being $<0.5$ is also indicative of close fit. Overall the model proves to be a close-fitting model acceptable for research (Kenny, 2020).

Table 1 Model statistic fit

\begin{tabular}{|l|l|l|l|l|}
\hline Goodness of Fit \\
\hline $\mathrm{p}>$ chi2 & TLI & CFI & SRMR & RMSEA \\
\hline 0.206 & 0.990 & 0.993 & 0.041 & 0.031 \\
\hline
\end{tabular}

To determine that the 3 constructs (psychological empowerment, employee voice and innovative work 
behavior) of this study are distinct from one another, this study tested for discriminant validity using the average variance extracted (AVE) analysis approach (Fornell \& Larcker, 1981). Table 2 gives evidence that the latent constructs i.e. psychological empowerment, voice and innovative work behavior are distinct and not highly correlated to each other. This is demonstrated as the discriminant values (square root of AVE) of each construct is greater than the correlation values between the constructs therefore establishing discriminant validity.

Table 2 Discriminant Validity

\begin{tabular}{|l|l|l|l|}
\hline \multicolumn{5}{|c|}{ Discriminant validity } \\
\hline Latent Variables & PsychologicalEmp & Voice & InnovativeWB \\
\hline PsychologicalEmp & $(0.950)$ & & \\
\hline Voice & 0.14 & $(0.897)$ & \\
\hline InnovativeWB & 0.076 & 0.13 & $(0.834)$ \\
\hline \multicolumn{4}{|l}{ The figures in parenthesis are the discriminant values }
\end{tabular}

Table 3 displays the correlation matrix amongst the constructs of this study (i.e. psychological empowerment, promotive voice, prohibitive voice and innovative work behavior). This reveals the direction and strength of the relationships existing between the variables. The constructs of the research are positively and significantly correlated according to the Pearson correlation generated by STATA 16, finding significance at $\mathrm{p}<$ $0.05, \mathrm{p}<0.01$

The Cronbach Alpha of each construct also proves to sustain a good internal consistency as reported by the scale reliability making the constructs valid for research, following verifications in early studies. The psychological empowerment scale reported 0.895 alpha reliability with 12 items. Voice scale recorded 0.854 alpha reliability with 10 scale items (Promotive voice recording .849 alpha reliability with 5 items and prohibitive voice reporting .695) and innovative work behavior reported 0.9039 displaying a very strong reliability scale with 10 items.

Table 3 Mean, Standard deviation, reliability and correlation of the study Descriptive Statistics, reliability and correlation of the study

\begin{tabular}{|l|l|l|l|l|l|l|l|}
\hline Variable & $\mathbf{M}$ & SD & $\mathbf{1}$ & $\mathbf{2}$ & $\mathbf{3}$ & $\mathbf{4}$ & $\mathbf{5}$ \\
\hline 1. PsychologicalEmp & 3.751 & 0.677 & $(0.895)$ & & & & \\
\hline 2. PromotiveV & 3.826 & 0.721 & $0.235^{*}$ & $(0.849)$ & & & \\
\hline 3. ProhibitiveV & 3.367 & 0.65 & $0.2821^{* *}$ & $0.595^{* *}$ & $(0.695)$ & & \\
\hline 4.InnovativeWB & 3.428 & 0.645 & $0.1607^{*}$ & $0.2357^{* *}$ & $0.23 * *$ & $(0.904)$ & \\
\hline Voice & 3.597 & 0.612 & $0.291^{* *}$ & $0.905^{* *}$ & $0.881^{* *}$ & $0.260^{* *}$ & $(0.854)$ \\
\hline
\end{tabular}

Note. $\mathrm{N}=200$. The figures in parenthesis are the values of the Cronbach's Alpha. ${ }^{\mathrm{p}}<0.05 * * \mathrm{p}<0.01$

\subsection{Hypothesis Testing}

Hypothesis 1 was accepted by this study as the results in Table 4 show that psychological empowerment positively and significantly influenced employee innovative work behavior $(B=0.153, p<0.05)$. Table 4 further indicates that about $3 \%$ of the variance in innovative work behavior is explained by psychological empowerment as revealed by the $\mathrm{R}^{\wedge} 2$ value.

Hypothesis 2 was accepted by this study because psychological empowerment positively and significantly influenced employee voice $(\mathrm{B}=0.247, \mathrm{p}<05)$ according to the report in Table 4 . Furthermore, the $\mathrm{R}^{\wedge} 2$ of 0.068 demonstrates that about $7 \%$ of the variance in voice is explained by psychological empowerment as revealed by Table 4.

Hypothesis 2a was accepted as psychological empowerment positively and significantly influenced employee promotive voice $(B=0.301, p<05)$. Additionally, the $\mathrm{R}^{\wedge} 2$ of 0.08 demonstrates that $8 \%$ of the variance in promotive voice is explained by psychological empowerment as revealed by Table 4 .

Hypothesis $2 \mathrm{~b}$ is accepted by the analysis of this study as in Table 4 shows that psychological empowerment positively and significantly influenced employee prohibitive voice $(B=0.226, p<05)$. Moreover, the result also reveal that about $6 \%$ of the variance in prohibitive voice behavior is explained by psychological empowerment.

Hypothesis 3 is accepted by this study for the reason that employee voice positively and significantly influences innovative work behavior $(B=0.274, p<05)$. The result also shows that about $7 \%$ of the variance of innovative work behavior is explained by promotive voice behavior as revealed in Table 4 .

Table 4 supports hypothesis $3 \mathrm{a}$ for the reason that promotive voice positively and significantly influences 
innovative work behavior $(\mathrm{B}=0.205, \mathrm{p}<05)$. The result also shows that about $5 \%$ of the variance of innovative work behavior is explained by promotive voice.

The empirical results shown in Table 4 supports hypothesis $3 \mathrm{~b}$ because prohibitive voice positively and significantly influences innovative work behavior $(B=0.234, p<05)$. The result also shows that about $6 \%$ of the variance of innovative work behavior is explained by prohibitive voice shown in Table 4 .

Table 4 Hypothesis testing - Linear regression

\begin{tabular}{|l|l|l|l|l|l|l|}
\hline Hypothesis & Dependent V. & Independent V. & $\begin{array}{l}\text { B (unstandardized } \\
\text { coefficient) }\end{array}$ & $\mathbf{R}^{\wedge} \mathbf{2}$ & p-value & Result \\
\hline H1 & InnovativeWB & PsychologicalEmp & 0.153 & 0.026 & 0.023 & Accepted \\
\hline H2 & Voice & PsychologicalEmp & 0.247 & 0.068 & 0.000 & Accepted \\
\hline H2a & PromotiveV & PsychologicalEmp & 0.301 & 0.08 & 0.000 & Accepted \\
\hline H2b & ProhibitiveV & PsychologicalEmp & 0.226 & 0.055 & 0.001 & Accepted \\
\hline H3 & InnovativeWB & Voice & 0.274 & 0.068 & 0.000 & Accepted \\
\hline H3a & InnovativeWB & PromotiveV & 0.205 & 0.053 & 0.001 & Accepted \\
\hline H3b & InnovativeWB & ProhibitiveV & 0.234 & 0.056 & 0.001 & Accepted \\
\hline
\end{tabular}

4.1.1 Mediation of voice

According to Baron \& Kenny (1986) mediation testing approach, the results displayed in Table 5 proves that employee voice mediates the relationship between psychological empowerment and innovative work behavior. This is ascertained as the direct path connecting Innovative work behavior and voice is positively significant whiles the path from psychological empowerment to innovative voice behavior, though having a positive correlation failed to sustain statistical significance. Notwithstanding the direct path from psychological empowerment to voice shows statistical significance. The ratio of the indirect effect over the total effect (rit) displayed reveals that about $65 \%$ of the effect of psychological empowerment on innovative work behavior is mediated by voice behavior.

Table 5 Hypothesis testing - Mediation of voice

\begin{tabular}{|l|l|l|}
\hline Mediation of Voice & \\
\hline Path & B (unstandardized coefficients) & p-value \\
\hline VoiceBehavior : PsychologicalEmp (X->M) & 0.315 & 0.000 \\
\hline InnovativeWB : Voice (M->) & 0.345 & 0.006 \\
\hline InnovativeWB : PsychologicalEmp (X->Y) & 0.059 & 0.144 \\
\hline Ratio of the indirect effect over the total effect (rit) $=0.647$ &
\end{tabular}

4.1.2 Mediation of promotive and prohibitive voice

The results displayed in Table 6 illustrates that promotive voice mediates the relationship between psychological empowerment and innovative work behavior according to Baron \& Kenny (1986) mediation testing approach. This is ascertained as the path connecting innovative work behavior to promotive voice is positively significant whereas the path from psychological empowerment to innovative work behavior, though having a positive correlation failed to sustain statistical significance. Notwithstanding the direct path from psychological empowerment to promotive voice shows statistical significance. The ratio of the indirect effect over the total effect (rit) shows that approximately $35 \%$ of the effect of psychological empowerment on innovative work behavior is mediated by promotive voice behavior.

Table 6 Hypothesis testing- Mediation of promotive voice

\begin{tabular}{|l|l|l|}
\hline Mediation of Promotive voice \\
\hline Path & B (unstandardized coefficients) & p-value \\
\hline PromotiveVB : PsychologicalEmp (X->M) & 0.381 & 0.000 \\
\hline InnovativeWB : PromotiveV (M->Y) & 0.179 & 0.005 \\
\hline InnovativeWB : PsychologicalEmp (X->Y) & 0.099 & 0.144 \\
\hline Ratio of the indirect effect over the total effect (rit) $=0.351$ & \\
\hline
\end{tabular}

Table 7 also demonstrates that the relationship between psychological empowerment and innovative work behavior is mediated by prohibitive voice. This is interpreted as the path from innovative work behavior to psychological empowerment proved to be statistically insignificant. However, the path from psychological 
empowerment to prohibitive voice and the path linking innovative work behavior and prohibitive voice attested for statistical significance. Lastly the ratio of the indirect effect over the total effect (rit) shows that about $31 \%$ of the influence of psychological empowerment on innovative behavior is mediated by prohibitive voice.

Table 7 Mediation of prohibitive voice behavior

\begin{tabular}{|l|l|l|}
\hline Mediation of Prohibitive voice behavior & B (unstandardized coefficients) & p-value \\
\hline Path & 0.226 & 0.001 \\
\hline ProhibitiveVB : PsychologicalEmp (X->M) & 0.208 & 0.003 \\
\hline InnovativeWB : ProhibitiveV (M->Y) & 0.106 & 0.113 \\
\hline InnovativeWB : PsychologicalEmp (X->Y) & \\
\hline Ratio of the indirect effect over the total effect (rit) $=0.307$ & \\
\hline
\end{tabular}

\section{Discussion}

This study aimed at investigating the nexus and effect of psychological empowerment on innovative work behavior in Ghana as it also further examined the mediation of supervisor rating of employee voice, an antecedent to innovative work behavior. The data analysis showed by the obtained results supported prior research that asserted that psychological empowerment is positively and strongly connected to innovative work behavior (Ghani et al., 2009). As a result, hypothesis 1 of this study, which proposed that psychological empowerment will positively influence employee innovative work behavior, was supported by this study. The outcome of the linear regression performed also advocates that increasing psychological empowerment will correspond to an increase in employee innovative work behavior.

Furthermore, the results produced by this research provides empirical evidence to support hypothesis $2,2 \mathrm{a}$ and $2 \mathrm{~b}$ which proposed that psychological empowerment will positively influence employee voice and by implication promotive $(\mathrm{H} 2 \mathrm{a})$ and prohibitive $(\mathrm{H} 2 \mathrm{~b})$ voice. The relationship between these constructs was positive and the regression analysis disclosed a positive unstandardized coefficient implying that psychological empowerment sustains the ability to augment employee voice by extension promotive and prohibitive voice. Meaning an increase in psychological empowerment levels will result to a corresponding increase in employee voice as a way of communicating ideas for organizational improvement.

In addition to the development of this empirical investigation, hypothesis $3,3 \mathrm{a}$ and $3 \mathrm{~b}$ were also supported by this study, which postulated that employee voice by implication promotive and prohibitive voice types will positively influence innovative work behavior. According to Pearson's correlation analysis, the correlations were significant and positive. Therefore inferring that promotive and prohibitive voice sustains the fortitude to augment innovative work behavior. Thus an increase in voice will potentially increase innovative work behavior levels.

Finally, this research analysis accepted hypothesis $4,4 \mathrm{a}$ and $4 \mathrm{~b}$ which hypothesized that employee voice, as also elaborated by promotive and prohibitive voice types will mediate the effect of psychological empowerment on innovative work behavior. Moving forward, the results ascertained that promotive voice had a greater impact in the mediation process than prohibitive voice by about $4 \%$ as evidenced by the reported ratio of the indirect effect over the total effect (rit). This means that promotive voice increased innovation work behavior among employees than prohibitive voice.

\subsection{Theoretical implication}

Theoretically, this study responded to the request for more research into the factors that influence innovative work behavior, and so adds to the domain of empirical study on this important topic by looking at the function of psychological empowerment and employee voice from a Ghanaian dataset. Furthermore, this research has helped to strengthen prior findings on the relevance of psychological empowerment, promotive, and prohibitive voice as important antecedents to innovative work behavior (Abdullatif et al., 2016; Çekmecelioğlu \& Özbăg, 2014; Miao et al., 2020). And therefor has also contributed to literature on voice and empowerment.

\subsection{Practical implication}

It is crucial to note that this study would help the government of Ghana and employers pay keen attention to organizing programs that integrate practices to enhance employee psychological empowerment levels as a way of provoking higher levels of performance and innovative capabilities, profitable for organizational and economic progress. This research also gives employers the confident assurance of the importance of encouraging employee voice in the workplace as it sustains the means of conveying innovative ideas and serves as a way of thwarting operational activities that may result to being an obstruction to organizational advancement 


\subsection{Limitation and future research}

As this study was designed to evaluate the effect of psychological empowerment on innovative work behavior in Ghana, it has several limitations that should be considered when interpreting the findings. To begin, the study employed a cross-sectional design to investigate the hypothesis; thus, this study reflects results obtained for a time though the theory was grounded on existing literature. For this very purpose, a longitudinal study approach would be proposed for future studies on this subject for more examination in determining and providing additional empirical evidence existing between the variables. Secondly, the data collection was conducted during a period where part of the country was on lockdown as some organizations were under strict government regulation to work from home, a strategy employed to mitigate the spread of Covid-19 in Accra, Ghana, thus this may have influenced the precision of the results. Future research could pay attention to a more favorable period for data collection possibly in a more formal working environment. Also, the data mainly were collected from 3 regions in Ghana and therefore may not express the total effect on the entire country. For this reason, this study suggests that future research should consider taking a larger sample, covering all of the 16 regions in Ghana. Additionally, given the constraints of a single-country study, it would be imperative for future studies to include a larger international sample to guarantee that results are comparable.

\section{Conclusion}

This study discovered that psychological empowerment and employee voice (promotive and prohibitive) positively and significantly influences innovative work behavior giving evidence to support the augmentation of the practice of the study in Ghana. Consequently, the study also showed that, employee voice by extrapolation promotive and prohibitive voice mediated the effect of psychological empowerment on innovative work behavior. This indicates that a psychologically empowered employee is more prone to explore and generate innovative ideas for the introduction of new products, techniques, and work procedures for innovation. And through the instrumentality of voice can also champion the idea for evaluation and for its implementation in order for the idea to find expression and relevance to organizational sustainable development.

\section{References}

Abdullatif, T. N., Johari, H., \& Adnan, Z. (2016). The Impact of Psychological Empowerment on Innovative Work Behavior Moderating by Quality Culture. European Journal of Business and Management, 8(17), 126-131. https://www.iiste.org/Journals/index.php/EJBM/article/view/31001

Akram, T., Lei, S., \& Haider, M. J. (2016). The impact of relational leadership on employee innovative work behavior in IT industry of China. Arab Economic and Business Journal, 11(2), 153-161. https://doi.org/10.1016/j.aebj.2016.06.001

Amabile, T. M. (1983). The Social Psychology of Creativity: A Componential Conceptualization. Journal of Personality and Social Psychology, 45, 357-376. https://doi.org/http://dx.doi.org/10.1037/00223514.45.2.357

Amabile, T. M. (1988). A model of creativity and innovation in organizations. Research in Organizational Behavior, 10, 123-167.

Artwatch, G. (2017). The state of creative arts in Ghana. https://www.artwatchghana.org/2017/04/

Asurakkody, T. A., \& Kim, S. H. (2020). Effects of knowledge sharing behavior on innovative work behavior among nursing Students: Mediating role of Self- leadership. International Journal of Africa Nursing Sciences, 12(May 2019), 100190. https://doi.org/10.1016/j.ijans.2020.100190

Avey, J. B., Wernsing, T. S., \& Palanski, M. E. (2012). Exploring the Process of Ethical Leadership: The Mediating Role of Employee Voice and Psychological Ownership. Journal of Business Ethics, 107(1), 2134. https://doi.org/10.1007/s10551-012-1298-2

Ayoub, D., Al-Akhras, D., Na'anah, G., \& Al-Madadha, A. (2018). The Relationship Between Psychological Empowerment and Creative Performance of Employees: Mediating Effect of Job Satisfaction in International Non-Governmental Organizations. European Scientific Journal, ESJ, 14(20), 217. https://doi.org/10.19044/esj.2018.v14n20p217

Babin, B. J., \& Anderson, R. E. (2014). on Multivariate Data Analysis Joseph F . Hair Jr . William C . Black Seventh Edition.

Bae, K. S., Chuma, H., Kato, T., Kim, D. B., and Ohashi, I. (2011). (2011). High performance work practices and employee voice: a comparison of Japanese and Korean workers. Ind. Relat., 50, 1-29. https://doi.org/10.1111/j.1468-232X.2010.00623.x N.

Baron, R.M. and Kenny, D. (1986). The Moderator-Mediator Variable Distinction in Social Psychological Research: Conceptual, Strategic, and Statistical Considerations. Journal of Personality and Social Psychology, 51, 1173-1182. https://doi.org/http://dx.doi.org/10.1037/0022-3514.51.6.1173

Basadur, M. (2004). Leading others to think innovatively together: Creative leadership. Leadership Quarterly, $15(1), 103-121$. 
Bhatnagar, J. (2005). The power of psychological empowerment as an antecedent to organizational commitment in indian managers. Human Resource Development International, 8(4), 419-433. https://doi.org/10.1080/13678860500356101

Chen, A. S. Y., \& Hou, Y. H. (2016). The effects of ethical leadership, voice behavior and climates for innovation on creativity: A moderated mediation examination. Leadership Quarterly, 27(1), 1-13. https://doi.org/10.1016/j.leaqua.2015.10.007

Connors, G., \& Press-Williams, J. (2016). Ghanaian Entrepreneurship and Innovation. 3-86.

De Dreu C. K. W., Nijstad B. A., Baas M., W. I. 2012. (2012). Working memory benefits creative insight, musical improvisation and original ideation through maintained task-focused attention. Pers. Soc. Psychol. Bull., 38, 656-669. https://doi.org/10.1177/0146167211435795

Detert, J. R., \& Burris, E. R. (2007). Leadership behavior and employee voice: Is the door really open? Academy of Management Journal, 50(4), 869-884. https://doi.org/10.5465/AMJ.2007.26279183

Dewettinck, K., \& Van Ameijde, M. (2011). Linking leadership empowerment behaviour to employee attitudes and behavioural intentions: Testing the mediating role of psychological empowerment. Personnel Review, 40(3), 284-305. https://doi.org/10.1108/00483481111118621

Dincer, H., Gencer, G., Orhan, N., \& Sahinbas, K. (2011). The Significance of Emotional Intelligence on the Innovative Work Behavior of Managers as Strategic Decision-Makers. Procedia - Social and Behavioral Sciences, 24, 909-919. https://doi.org/10.1016/J.SBSPRO.2011.09.052

Durrah, O., Khdour, N., Al-Abbadi, S., \& Saif, N. (2014). The impact of psychological empowerment on the effectiveness of job performance: A field study on the Jordanian private banks. European Journal of Business and Management, 6(32), 176-189.

Edmond, C. (2019). Ghana will grow faster than any other economy this year, the IMF says why. https://www.weforum.org/agenda/2019/05/ghana-is-set-to-be-the-worlds-fastest-growing-economy-thisyear-according-to-the-imf/

Fornell, C., \& Larcker, D. F. (1981). Evaluating Structural Equation Models with Unobservable Variables and Measurement Error. Journal of Marketing Research, 18(1), 39. https://doi.org/10.2307/3151312

Fosu, A. K. (2001). Emerging Africa: The Case of Ghana. Oecd, 1-39. https://search.oecd.org/countries/ghana/2674859.pdf

Ghani, N. A. A., Hussin, T. A. B. S. bin R., \& Jusoff, K. (2009a). Antecedents of Psychological Empowerment in the Malaysian Private Higher Education Institutions. International Education Studies, 2(3). https://doi.org/10.5539/ies.v2n3p161

Ghani, N. A. A., Hussin, T. A. B. S. R., \& Jusoff, K. (2009b). The impact of psychological empowerment on lecturers' innovative behaviour in Malaysian private higher education institutions. Canadian Social Science, 5(4), 54-63.

Howell, J. \& Higgins, C. (1990). Champions of change: identifying, understanding, and supporting champions of technological change, Organizational Dynamics,. $19(1), \quad 40-55$. https://doi.org/http://dx.doi.org/10.1037/0021-9010.86.2.326

Ikenwa, C. (2020). Ghana natural resources: List of natural resources found in Ghana. https://nigerianinfopedia.com.ng/ghana-natural-resources-found-in-ghana/

Jong, J. P. J. D., \& Hartog, D. N. Den. (2008). Innovative Work Behavior: Measurement and Validation. Scientific Analysis of Entrepreneurship and SMEs, November, 1-27.

Kanter, R. M. (1988). When a thousand flowers bloom: structural, collective and social conditions for innovation in organization, Research in Organizational behavior. 10, 169-211.

Kenny, D. A. (2020). Measuring model fit. http://davidakenny.net/cm/fit.htm

King N. \& Anderson N. (2002). Managing innovation and change: a critical guide for organizations, Thomson, London.

Liang, J., Farh, C. I. C., \& Farh, J. L. (2012). Psychological antecedents of promotive and prohibitive Voice: A two-wave examination. Academy of Management Journal, 55(1), 71-92. https://doi.org/10.5465/amj.2010.0176

Martins, A. T. (2021). What are the benefits of innovation in business. https://www.profitableventure.com/benefits-innovation-business/

Maynes, T. D., \& Podsakoff, P. M. (2014). Speaking more broadly: An examination of the nature, antecedents, and consequences of an expanded set of employee voice behaviors. Journal of Applied Psychology, 99(1), 87-112. https://doi.org/10.1037/a0034284

Meng, L., Liu, Y., Liu, H., Hu, Y., Yang, J., \& Liu, J. (2015). Relationships among structural empowerment, psychological empowerment, intent to stay and burnout in nursing field in mainland China-based on a cross - sectional questionnaire research. International Journal of Nursing Practice, 21(3), 303-312.

Methods for Testing Discriminant Validity. (2011). Management and Marketing Journal, IX(2), $217-224$.

Miao, R., Lu, L., Cao, Y., \& Du, Q. (2020). The high-performance work system, employee voice, and innovative 
behavior: The moderating role of psychological safety. International Journal of Environmental Research and Public Health, 17(4). https://doi.org/10.3390/ijerph17041150

Mumford, M.D., W. A. B. \& R. R.-P. (1997). Thinking creativity at work: organizational influence on creative problem solving. Journal of Creative Behavior, 31, 7-17.

NEIP. (2020). National Entrepreneurship and Innovation Programme - A government of Ghana initiative. http://neip.gov.gh/

Niesen, W., Van Hootegem, A., Elst, T. Vander, Battistelli, A., \& De Witte, H. (2017). Job insecurity and innovative work behaviour: A psychological contract perspective. Psychologica Belgica, 57(4), 174-189. https://doi.org/10.5334/pb.381

Oduro, S., \& Nyarku, K. M. (2018). Incremental Innovations in Ghanaian SMEs: Propensity, Types, Performance and Management Challenges. Asia-Pacific Journal of Management Research and Innovation, 14(1-2), 10-21. https://doi.org/10.1177/2319510x18810034

Örnek, A. Ş., \& Ayas, S. (2015). The Relationship between Intellectual Capital, Innovative Work Behavior and Business Performance Reflection. Procedia - Social and Behavioral Sciences, 195(July), 1387-1395. https://doi.org/10.1016/j.sbspro.2015.06.433

Parnes, S.J., R. B. N. \& A. M. B. (1977). Guide to creative action, New York: Charles Scribner's Sons.

Quartey-Papafio, T. K., Javed, S. A., \& Liu, S. (2021). Forecasting cocoa production of six major producers through ARIMA and grey models. Grey Systems: Theory and Application, 11(3), 434-462. https://doi.org/10.1108/gs-04-2020-0050

Raub, S., \& Robert, C. (2013). Empowerment, Organizational Commitment, and Voice Behavior in the Hospitality Industry: Evidence from a Multinational Sample. Cornell Hospitality Quarterly, 54(2), 136148. https://doi.org/10.1177/1938965512457240

Saether, E. A. (2019). Motivational antecedents to high-tech R\&D employees' innovative work behavior: Selfdetermined motivation, person-organization fit, organization support of creativity, and pay justice. The Journal of High Technology Management Research, 30(2), 100350. https://doi.org/10.1016/J.HITECH.2019.100350

SALMAN, K., HUSSAIN AWAN, S., \& HABIB, N. (2020). Link Between Employee Voice and Organizational Citizenship Behavior: Moderating Role of Psychological Safety. International Review of Management and Business Research, 9(3), 242-258. https://doi.org/10.30543/9-3(2020)-19

Scott, S. G., \& Bruce, R. A. (1994). Determinants of Innovative Behavior: A Path Model of Individual Innovation in the Workplace Author ( $\mathrm{s}$ ): Susanne G. Scott and Reginald A . Bruce Published by: Academy of Management Stable URL: http://www.jstor.org/stable/256701 REFERENCES Linked refe. The Academy of Management Journal, 37(3), 580-607.

Seibert, S. E., Wang, G., \& Courtright, S. H. (2011). Antecedents and Consequences of Psychological and Team Empowerment in Organizations: A Meta-Analytic Review. Journal of Applied Psychology, 96(5), 9811003. https://doi.org/10.1037/a0022676

Spreitzer, G. M. (1995). Psychological empowerment in the workplace: Dimensions, measurement, and validation. Academy of Management Journal, 38(5), 1442-1465.

Sun, L. Y., Zhang, Z., Qi, J., \& Chen, Z. X. (2012). Empowerment and creativity: A cross-level investigation. Leadership Quarterly, 23(1), 55-65. https://doi.org/10.1016/j.leaqua.2011.11.005

Thomas, K. W. and V. B. A. (1990). Cognitive elements of empowerment: An "Interpretive" model of intrinsic task motivation. Academy of Management Review, 15, 666-681.

Van de Ven, A. (1986). Central problems in the management of innovation. Management Science, 32, 590-607.

Van Dyne, L., \& LePine, J. A. (1998). Helping and voice extra-role behaviors: Evidence of construct and predictive validity. Academy of Management Journal, 41, 108-119. https://doi.org/10.2307/256902

Van Dyne, L., Ang, S., \& Botero, I. (2003). Conceptualizing employee silence and employee voice as multidimensional constructs. Journal of Management Studies, 40, 1359-1392. https://doi.org/10.1111/1467-6486.00384

Volery, T., \& Tarabashkina, L. (2021). The impact of organisational support, employee creativity and work centrality on innovative work behaviour. Journal of Business Research, 129(March), $295-303$. https://doi.org/10.1016/j.jbusres.2021.02.049

Walumbwa, F. O., Morrison, E. W., \& Christensen, A. L. (2012). (). Ethical leadership and group in-role performance: The mediating roles of group conscientiousness and group voice. , (5), . The Leadership Quarterly, 23(5), 953-964. https://doi.org/10.1016/j.leaqua.2012.06.004

Wei, X., Hisrich, R. D., \& Peng, X. (2020). Chinese employees' psychological empowerment and voice behavior: Organizational justice as a moderator. Social Behavior and Personality: An International Journal, 48(6), e8792.

West M.A., F. J. L. (n.d.). (Eds.), Innovation and creativity at work: Psychological and Organizational Strategies, John Wiley Sons, Ltd., Chichester (1990). 
Yan, A., \& Xiao, Y. (2016). Servant leadership and employee voice behavior: a cross-level investigation in China. SpringerPlus, 5(1). https://doi.org/10.1186/s40064-016-3264-4

Zhang Xiaomeng and Bartol Kathryn M. (2010). Linking empowering leadership and employee creativity: the influence of psychological empowerment, intrinsic motivation, and creative process engagement. The Academy of Management Journal, 53(1), 107-128.

Zhou, J. and George, J. M. (2001). When job dissatisfaction leads to creativity: Encouraging the expression of voice. Academy of Management Journal, 44, 682-696. 